\title{
Testování zařízení Mini-JET pro stanovení erozních charakteristik orné půdy
}

\section{MICHAL VRÁNA, DAVID ZUMR, JOSEF KRÁSA, TOMÁŠ DOSTÁL, JOHN S. SCHWARTZ}

\author{
Klíčová slova: Mini-JET - kritické tečné napětí - koeficient erodovatelnosti - nesoudržná půda
}

\section{SOUHRN}

Článek popisuje metodu stanovení erodovatelnosti nesoudržných zemědělských půd pomocí měěení kritického tečného napětí. Pro určení kritického tečného napětí byl použit tzv. „Jet Erosion Test“ (JET). Měření bylo provedeno pomocí modifikované zmenšené verze zařízení Mini-JET. Zařízení je velmi vhodné pro terénní měření, nebot’ je malé, lehké, spotřebuje relativně nízké množství vody a na jeho obsluhu postačí jedna osoba. Princip měření kritického tečného napětí půdy je založen na sledování rychlosti tvorby erozního kráteru, který je vymílán působením vodního paprsku o známé kinetické energii. Z průběhu geneze erozního kráteru Ize vypočítat erozní parametry půdy, jako jsou kritické tečné napětí a koeficient erodovatelnosti.

Všechny Mini-JET experimenty byly provedeny na experimentálních plochách u obce Řisuty a byly pro ně využity dva odlišné typy půdního povrchu. U pưdního povrchu byly zjištovány pưdní charakteristiky (objemová hmotnost, zrnitostní složení, objemová vlhkost, stabilita půdních agregátů a obsah organického uhlíku). Celkem bylo provedeno 75 simulací.

U vypočtených erozních veličin byla zjištěna velká variabilita, která je charakteristická pro nesoudržné typy půdních povrchů. Přesto jsou stanovené hodnoty koeficientu erodovatelnosti srovnatelné s publikovanými hodnotami, a mohou tak být využitelné pro implementaci v erozních modelech. Na základě provedených testů Ize proto konstatovat, že metoda je využitelná i na zemědělských půdách. Pro získání reprezentativních hodnot erodovatelnosti je vzhledem k vysoké prostorové heterogenitě prostředí třeba provést dostatečný počet replikací.

\section{ÚVOD}

Eroze půd je přirozený proces, který v dlouhodobém časovém měřítku přetváří reliéf krajiny. Eroze je působena kombinací různých faktorů. Klíčové jsou vlastnosti půdy a její schopnost odolávat působení erozních činitelů (dopadu deštových kapek a povrchovému odtoku vody). Problematická je eroze zrychlená, při níž se odplavují pưdní částice a agregáty tak rychle, že nemohou být nahrazovány pomalejším pưdotvorným procesem. Zrychlená eroze je často zpưsobena zásahy člověka v krajině [1]. Př́činami zrychlené eroze v České republice jsou kromě jiného kolektivizovaná zemědělská krajina, přetrvávající intenzifikace zemědělství a pěstování nevhodných plodin na nevhodných pozemcích [2]. Tím dochází k postupnému zmenšování mocnosti půdního profilu, a tedy ke snižení úrodnosti půdy a následným ztrátám v zemědělství. Vlivem transportu půdních částic se pak sediment usazuje v patách svahu, ve vodních tocích a nádržích.
Erodovatelnost půdy je charakteristika, která popisuje náchylnost konkrétního půdního povrchu k erozi [3]. Vyšší míra erodovatelnosti vede k vyššímu smyvu pro konkrétní erozně účinnou srážku při zachování ostatních počátečních a okrajových podmínek. Z toho důvodu vstupuje erodovatelnost povrchu půdy jako parametr do řady fyzikálně založených erozních modelů [3-6]. $\checkmark$ závislosti na koncepci modelu je erodovatelnost vyjádřena různými způsoby a je odvozena z různých charakteristik půdy (fyzikálních i chemických). Za hlavní určující parametry erodovatelnosti jsou obvykle považovány: zrnitostní složení, obsah organického uhlíku, skeletovitost, stabilita půdních agregátů a hydraulická vodivost [7].

$\checkmark$ modelech matematicky popisujících erozní proces [6] je iniciální erodovatelnost mezirýhové, respektive plošné eroze závislá na kritickém tečném napětí daného povrchu půdy [8], na němž se kromě výše uvedených vlastností půdy podílí i stav povrchu, tedy nakypřenost, krusta vytvořená předchozími srážkami a konsolidací při vysychání, drsnost povrchu aj. Kritické tečné napětí je hodnota smykového napětí vyvolaná kinetickou energií vodního proudu (srážka, povrchový odtok), od kterého začne být povrch půdy rozrušován, jeho struktura se rozpadá a půdní částice (nebo rozplavené agregáty) začínají být unášeny vodním proudem. Kritické napětí lze stanovit na základě experimentů s deštovým simulátorem nebo pomocí umělého výronu vody na sklonitém půdním povrchu. Tyto experimenty jsou časově a finančně náročné. V praxi se proto $v$ matematických modelech často využívá neprímých odvození na základě snadno měřitelných charakteristik půdy. Nalezení spolehlivé metody pro přímé měření hodnot erodovatelnosti půdy, kterou by bylo možno provádět rychle, snadno a ve větším počtu opakování, by bylo velkým prínosem pro spolehlivější stanovení erozní ohroženosti zemědělských půd a následné navrhování protierozních opatření.

Cílem této práce je představení metody stanovení erodovatelnosti nesoudržných zemědělských půd pomocí měření kritického tečného napětí. Pro určení kritického napětí je testován tzv. „Jet Erosion Test“, prováděný s využitím modifikovaného zařízení Mini-JET. Toto zařízení bylo doposud použiváno pro stanovování kritického tečného napětí soudržných půd (zejména pro posouzení stability břehů a dna vodních toků). Metoda je ve světě relativně rozšířená [9-11]. Její využití pro povrch zemědělské půdy je však zcela inovativní a jedná se o první takové využití popisovaného zařízení [12].

\section{METODIKA}

Princip měření kritického tečného napětí půdy je založen na sledování rychlosti tvorby erozního kráteru působením vodního paprsku o známé kinetické energii. Z průběhu geneze erozního kráteru lze vypočítat erozní parametry půdy, jako jsou kritické tečné napětí a koeficient erodovatelnosti. Experimenty jsou 
prováděny s využitím zařizení Mini-JET, které je popsáno dále. Zařízení je velmi vhodné pro terénní měření, nebơt je malé, lehké, spotřebuje relativně nízké množství vody a na jeho obsluhu postačí jedna osoba.

Při hodnocení erodovatelnosti půdy Ize předpokládat, že rychlost eroze $\varepsilon_{\mathrm{r}}\left[\mathrm{m} . \mathrm{s}^{-1}\right]$ je úměrná efektivnímu tečnému napětí. Eroze nastává v momentu, kdy efektivní tečné napětí začne převyšovat kritické smykové napětí [11]:

$$
\varepsilon_{r}=k_{d}\left(\tau_{e}-\tau_{c}\right)
$$

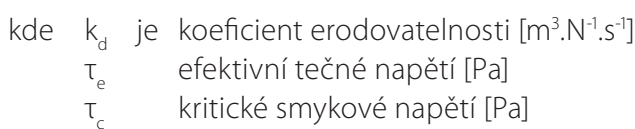

\section{JET EROSION TEST}

JET (Jet Erosion Test) je technika používaná při studiu eroze a mechanických vlastností půdy. Experimentální vybavení a metodika pro JET test byly vyvinuty Hansonem a kol. [13] ve Spojených státech amerických. Princip spočívá v monitorování eroze půdy vyvolané kolmo aplikovaným proudem vody.

Proud vody generovaný konstantním tlakem prochází tryskou a naráží na povrch půdy. Půdní povrch je během experimentu zaplaven, tryska je zcela ponořená ve vodě, tudíž následné výpočty erozních parametrů probíhají na základě dynamiky ponořeného paprsku, jak ve své publikaci popsali Hanson a Cook [14]. Vodní paprsek vycházející z trysky působí na povrch půdy smykovou silou, čímž se začne vytvářet erozní kráter.

Rozložení tečného napětí pod vodním paprskem není rovnoměrné, teoreticky je ve středu nárazové zóny nulové a zvyšuje se se vzrůstající radiální vzdáleností od středu až na okraj tryskového proudu. Poté se toto napětí se vzrưstající vzdáleností snižuje. JET analýza je založena na předpokladu, že maximální smyková síla vodního paprsku způsobí maximální prohloubení erozního kráteru [11].

Odečet hloubky erozního kráteru se provádí v průběhu erozního experimentu. Počáteční doba měření by měla být co nejmenší, aby bylo možné dosáhnout co nejpresnějšího průběhu hloubky erozního kráteru, jelikož největší smyková síla působí na začátku testu a s rostoucí hloubkou kráteru klesá. Test je považován za dokončený, jakmile dosáhne hloubka erozního kráteru maxima (nedochází k dalšímu prohlubování) [15].

V zásadě existují dvě základní konstrukce JET zařízení. Tím starším je JET zařízení, jež je přibližně 1 metr vysoké s průměrem základového prstence 300 mm a průměrem trysky 6,4 mm [16]. Původní JET zařízení je také vybaveno zásobníkem na vodu, pomocí kterého se v systému udržuje konstantní tlak na trysce. Novější a menší varianta zařízení, Mini-JET, je asi 0,5 metru vysoká, s průměrem základového prstence 100 mm a průměrem trysky 3,2 mm [17, 18]. Zařízení není osazeno zásobníkem na vodu, nýbrž je závislé na externím př́ivodu vody. Obě konstrukční varianty se používají jak za jasně definovaných podmínek v laboratoři, tak i pro terénní měření.

\section{MINI-JET ZAŘíZENÍ}

Jde o menší verzi původního zařízení JET. Přímou předlohou pro zde prezentovaný Mini-JET je zařízení, které pro výzkum eroze břehových hran vodních toků v Tennessee (USA) používali Mahalder a kol. [9]. Pro potřeby experimentů na nesoudržné ornici bylo zařízení upraveno. Modifikace spočívá v úpravě průměru základového prstence, jenž byl zvětšen tak, aby při erozi nesoudržné ornice nedocházelo k rozšírení erozního kráteru až k prstenci (obr. 1). Návrh této modifikace byl vytvořen na Katedře hydromeliorací a krajinného inženýrství
ČVUT v Praze. Př́stroj byl následně vyroben na zakázku firmou CS Plasting, s. r. o. Druhou významnou úpravou je systém regulace tlaku vody, který umožňuje nastavení nízké kinetické energie vodního paprsku.
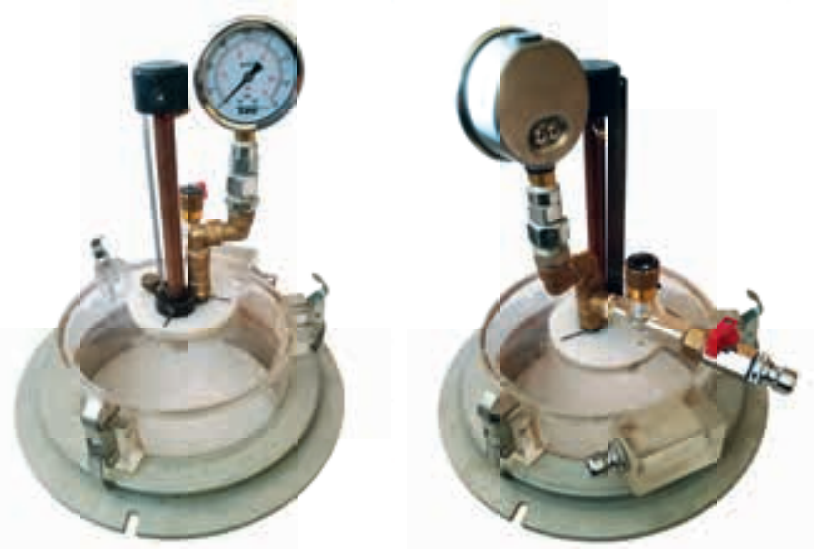

Obr. 1. Modifikovaná konstrukce zařízení Mini-JET Fig. 1. Modified design of the Mini-JET device

Modifikovaný Mini-JET je schematicky, včetně jednotlivých komponent, ukázán na obr. 2 a 3. Potřebný tlak vody je zajištován elektrickým čerpadlem. Následná úprava tlaku na trysce se provádí pomocí ventilu s jemnou regulací (1), který je umístěn na prívodní armatuře (2). Tlak vody je kontrolován pomocí manometru (3), umístěném v horní části přístroje. Jako u původní konstrukce JET je zařízení vybaveno otočnou deskou (4), na níž je připevněna tryska (5) společně s měřidlem hloubky erozního kráteru (6). Pomocí otáčení je zařízení $\checkmark$ poloze pracovní (obr. 2), nebo čtecí (obr. 3). Základový prstenec (7) je oddělitelný od zaplavovací nádrže (8) a během experimentu je kotvený k zaplavovací nádrži pomocí kovových svorek (9).

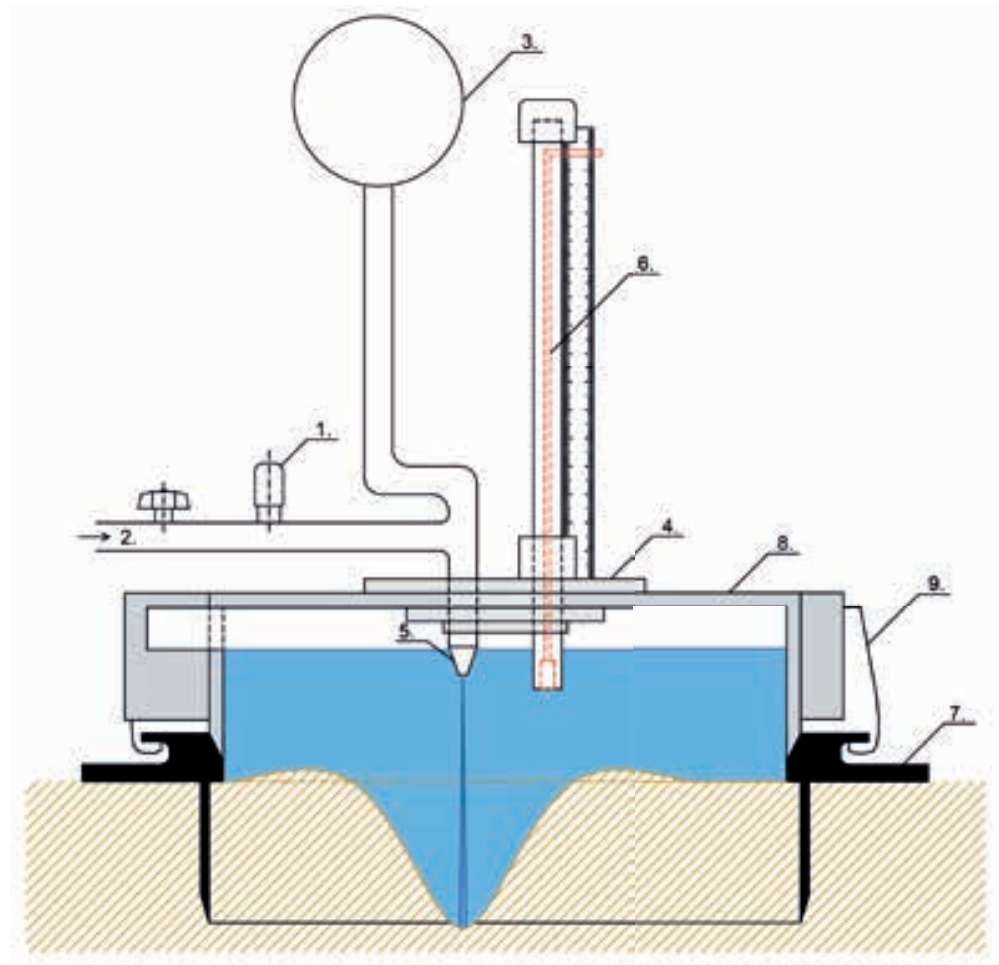

Obr. 2. Schéma zařizení Mini-JET - pracovní poloha

Fig. 2. Schema of the Mini-JET device - working position 


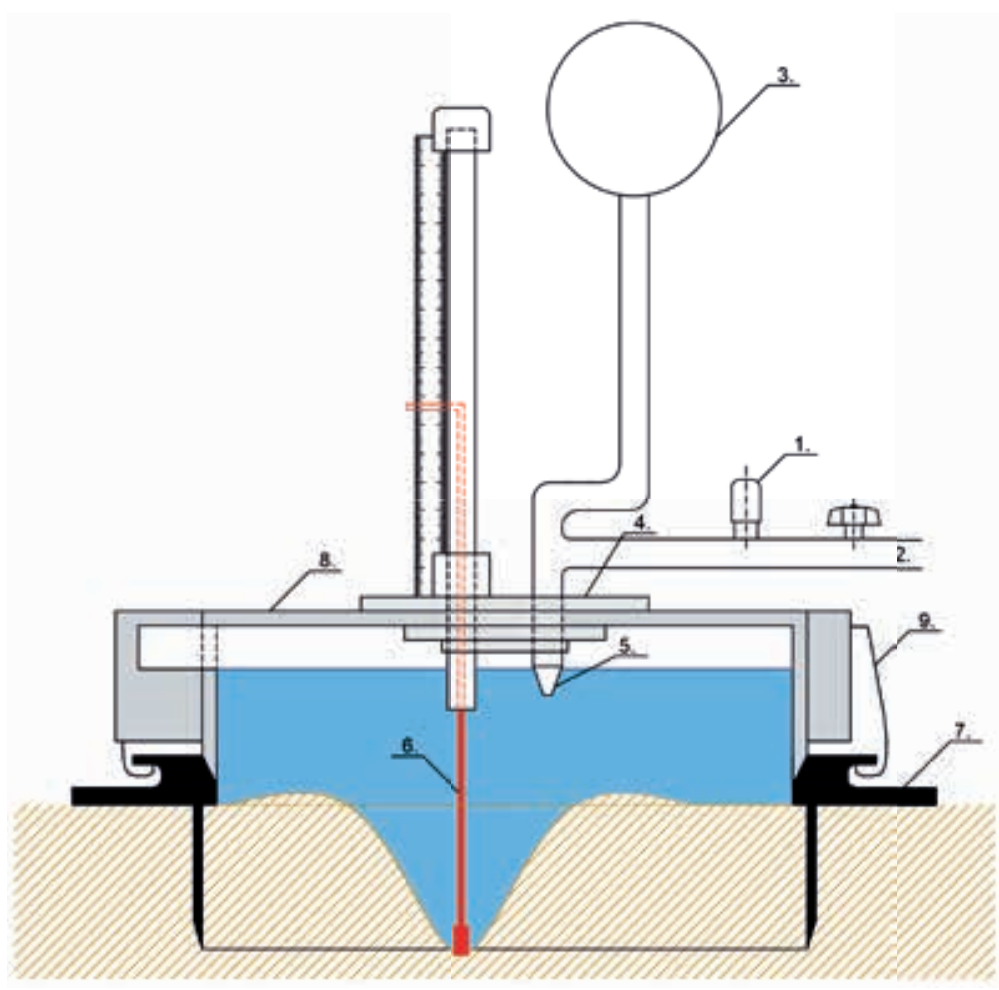

Obr. 3. Schéma zařízení Mini-JET - čtecí poloha

Fig. 3. Schema of the Mini-JET device - reading position

\section{KALIBRACE ZAŘÍZENÍ}

Pro každý konkrétní př́stroj je třeba stanovit kalibrační koeficient, který je následně použit pro výpočty erozních parametrů [19]. Kalibrační koeficient odpovídá ztrátám v hydraulických komponentách zařízení, jež jsou specifické pro každý výrobek podle jednotlivých armatur, jejich parametrů a použitých materiálů (zařízení se nevyrábí sériově a každý kus je originálem). Pro výpočet kalibračního koeficientu je potřeba znát průtok tryskou při různých pracovních tlacích. Výpočet kalibračního koeficientu byl proveden podle Mahaldera [19].

Dalším potřebným parametrem je tzv. teoretický průtok $\mathrm{Q}_{\text {teo }}$, který představuje maximální průtok prístrojem při nulových ztrátách:

$$
Q_{\text {teo }}=A \cdot \sqrt{2 g h}
$$

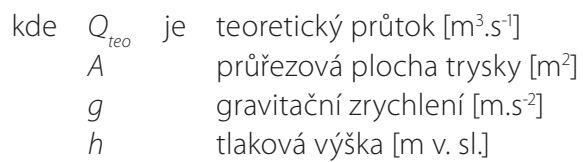

Výsledky kalibrace jsou znázorněny graficky (obr. 4), kde na ose x jsou hodnoty vypočteného teoretického průtoku a na ose y jsou hodnoty měěeného průtoku. Jednotlivými body byla proložena přímka, jejíž směrnice odpovídá kalibračnímu koeficientu [19].

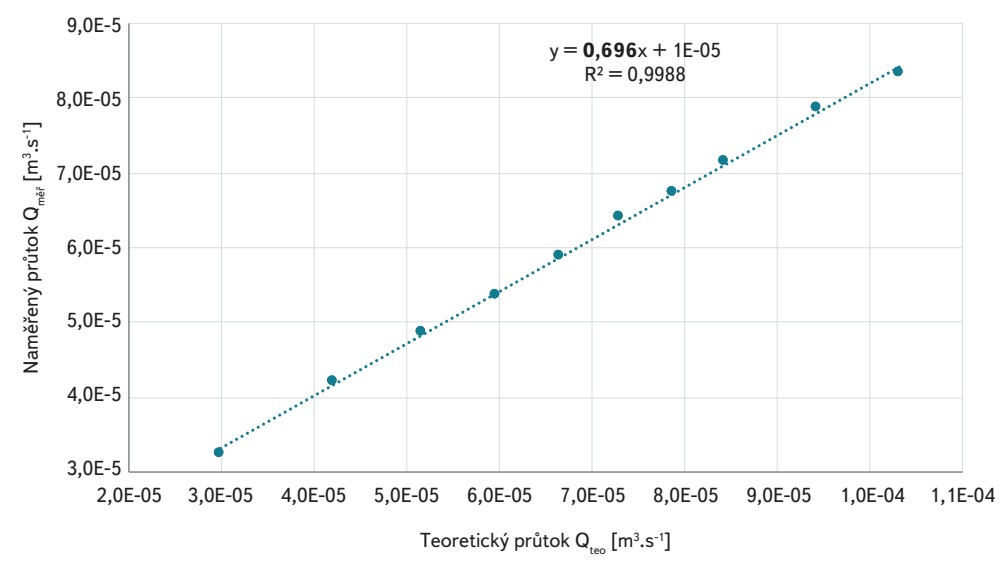

Obr. 4. Určení kalibračního koeficientu, který v případě konkrétního zařízení odpovídá směrnici př́mky 0,696

Fig. 4. Determination of the calibration coefficient, which in the case of the specific device corresponds a value of 0.696

\section{EXPERIMENTÁLNÍ LOKALITA A TERÉNNÍ MĚŘENÍ}

Všechny Mini-JET experimenty byly provedeny na experimentálních plochách u obce Řisuty. Obec Řisuty leží v okrese Kladno asi 5 km západně od Slaného. Experimentální plochy se nacházejí v nadmořské výšce cca 320 m n. m. Klima je suché a teplé, s mírnou zimou a velmi krátkým trváním sněhové pokrývky. Průměrná roční teplota se tu pohybuje mezi 8 a $9^{\circ} \mathrm{C}$. Průměrný roční srážkový úhrn bývá okolo 500 mm. Půdním typem je kambizem modální (BPEJ 1.33.11), z hlediska zrnitostního složení jde o prachovitou hlínu (tab. 1). Experimentální měření se zařízením Mini-JET probíhá nárazově od léta roku 2020.

Cílem terénních měření bylo otestovat zařízení v polních podmínkách, vybrat nejvhodnější provozní tlak pro dané podmínky a zjistit, zda výsledky budou použitelné pro stanovení erozních parametrů testované půdy. Jelikož metodika výpočtu erozních parametrů počítá s homogenním půdním prostředím, byly zvoleny dva typy půdního povrchu, které se nejvíce přibližují homogennímu prostředí.

Na experimentální ploše č. 1 se nacházel tzv. čerstvě vytvořený válcovaný úhor (obr. 5) o průměrné objemové hmotnosti cca 1,35 g. $\mathrm{cm}^{-3}$. Jde o půdní povrch, který je srovnávacím stavem pro měření smyvu během kampaní s deštovým simulátorem pro určování C-faktoru [20]. Povrch je připravován v den simulace nakypřením půdy kultivátorem, srovnáním povrchu hráběmi a následným uválcováním.

Na experimentální ploše č. 2 se nacházel povrch po běžné prípravě pozemku na setové lože. Príprava spočívala v orbě do hloubky $26 \mathrm{~cm}$, podmítce do hloubky 20 cm a v setí žita po spádnici. Tento povrch je soudržnější než výše uvedený válcovaný úhor, protože od orby do prvního Mini-JET experimentu uplynulo 22 dní, během nichž tvořil srážkový úhrn 35 mm, díky čemuž se půda stala kompaktnější (obr. 5). To dokazuje i objemová hmotnost půdy $(1,81-1,85$ g.cm³), která je vyšší než u válcovaného úhoru (tab. 1).

Celkem bylo provedeno 75 experimentů, z toho 13 na válcovaném úhoru a 62 na setovém loži. Na válcovaném úhoru bylo uskutečněno výrazně méně simulací, jelikož experimentální měření s přístrojem začalo v létě 2020 a většina měření probíhala až na podzim 2020. V tomto období je již velmi obtížné připravit referenční plochu (především kvůli vysoké vlhkosti půdy). Druhým důvodem je poměrně složité provádění experimentu na nakypřeném úhoru, úspěšnost simulací na utuženějším setovém loži byla vyšší. 


\begin{tabular}{|c|c|c|c|c|c|c|c|c|}
\hline \multirow[b]{2}{*}{$\begin{array}{l}\text { Experimentální } \\
\text { plocha }\end{array}$} & \multirow[b]{2}{*}{$\begin{array}{l}\text { Povrch } \\
\text { (datum) }\end{array}$} & \multicolumn{3}{|c|}{ Zrnitostní složení půdy } & \multirow{2}{*}{$\begin{array}{l}\text { Objemová } \\
\text { hmotnost } \\
{\left[\mathrm{g} \cdot \mathrm{cm}^{-3}\right]}\end{array}$} & \multirow{2}{*}{$\begin{array}{l}\text { Objemová } \\
\text { vlhkost před } \\
\text { experimentem } \\
\text { [\%] }\end{array}$} & \multirow{2}{*}{$\begin{array}{l}\text { Stabilita agregátů } \\
\text { (Nimmo and } \\
\text { Perkins) [\%] }\end{array}$} & \multirow{2}{*}{$\begin{array}{l}\text { Obsah } \\
\text { organického } \\
\text { uhlíku [\%] }\end{array}$} \\
\hline & & $\begin{array}{l}\text { jíl } \\
\text { [\%] }\end{array}$ & $\begin{array}{l}\text { prach } \\
{[\%]}\end{array}$ & $\begin{array}{l}\text { písek } \\
\text { [\%] }\end{array}$ & & & & \\
\hline 1 & $\begin{array}{l}\text { Válcovaný úhor } \\
\text { (8.7.2020) }\end{array}$ & 9,0 & 56,3 & 34,7 & 1,35 & 19,5 & neurčeno & neurčeno \\
\hline 1 & $\begin{array}{l}\text { Válcovaný úhor } \\
\text { (10.9.2020) }\end{array}$ & 9,2 & 56,2 & 34,6 & 1,34 & 19,2 & neurčeno & neurčeno \\
\hline 2 & $\begin{array}{l}\text { Setové lože } \\
(21.10 .2020)\end{array}$ & 8,3 & 54,5 & 37,2 & 1,82 & 29,3 & 55,9 & 1,48 \\
\hline 2 & $\begin{array}{l}\text { Setové lože } \\
\text { (24. 10. 2020) }\end{array}$ & 8,9 & 57,3 & 33,8 & 1,85 & 30,2 & 60,8 & 1,43 \\
\hline 2 & $\begin{array}{l}\text { Set’ové lože } \\
(25.10 .2020)\end{array}$ & 9,9 & 57,0 & 33,1 & 1,81 & 32,3 & 57,8 & 1,68 \\
\hline
\end{tabular}
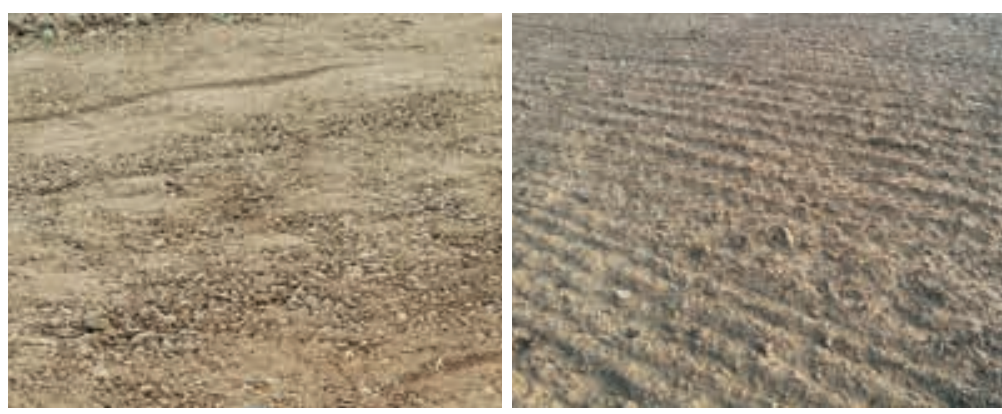

Obr. 5. Válcovaný úhor na experimentální ploše č. 1 (vlevo) a setové lůžko na experimentální ploše č. 2 (vpravo)

Fig. 5. Fallow on experimental area No. 1 (left) and seedbed on experimental area No. 2 (right)

Celý systém zařízení Mini-JET byl před experimentem zkompletován a řádně odvzdušněn. U následného výběru vhodného místa pro simulaci bylo potřeba dát si pozor na prítomnost předmětů, které by mohly narušit tvorbu erozního kráteru. Předně to jsou kameny, rostlinné zbytky, kořeny atd. Tyto předměty ovlivňují tvorbu erozního kráteru a měření znehodnocují. Základový prstenec musí být instalován do půdy vodorovně. Při velkém sklonu by nemusela být tryska ponořena ve vodě, tudíž by neplatily vztahy pro následné výpočty erozních parametrů. Dále byly odebrány neporušené půdní vzorky pro stanovení fyzikálních půdních charakteristik.

Cílem měření je co nejpresněji zaznamenat průběh tvorby erozního kráteru $\checkmark$ čase. Důležité je nastavení vhodného tlaku vody. Pokud by byl př́liš vysoký, kráter se v nesoudržné půdě vytvoří okamžitě. Naopak pokud by byl tlak př́liš nízký, erozní kráter se nevytvoří. Pro válcovaný úhor byl použit tlak okolo 1 psi $(6,9 \mathrm{kPa})$ a pro setové lůžko byly nastaveny tlaky mezi 3 a 4 psi $(20,7$ a 27,6 kPa). Použité tlaky vody byly určeny predevším na základě zkušeností operátora zařízení. Jelikož válcovaný úhor je méně soudržný než set’ové lože, bylo potřeba použít na válcovaný úhor podstatně nižší tlak než na setové lože, aby bylo možné zaznamenat průběh tvorby erozního kráteru v čase. Při vysokém tlaku je kráter vytvořen okamžitě. Vodní paprsek se na půdní povrch pouštěl v intervalech, jež se s prohlubováním erozního kráteru prodlužovaly. Mezi aplikacemi vodního paprsku (obr. 2) se přístroj otáčel do čtecí polohy (obr. 3) a měřil se průběh tvorby kráteru, respektive jeho hloubka. Jako počáteční doba aplikace proudu vody byla zvolena hodnota 5 s. Měření bylo ukončeno, když se při posledních třech měřeních o délce minimálně 30 s hloubka erozního kráteru nezvětšovala (obr. 6). Při měření hloubky erozního kráteru bylo potřeba spouštět měřidlo opatrně. Při samovolném puštění by měřidlo mohlo prohloubit kráter, a mohlo by tak dojít ke zkreslení výsledků.

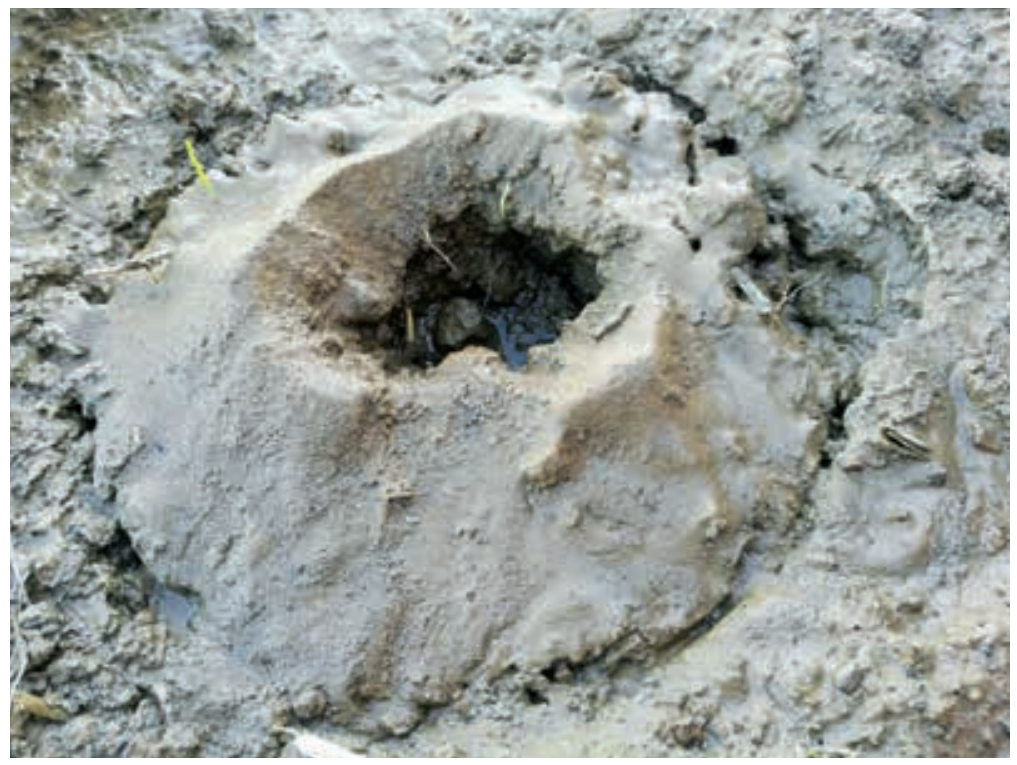

Obr. 6. Erozní kráter po simulaci

Fig. 6. Erosion crater after simulation

\section{VÝPOČET EROZNÍCH PARAMETRŮ}

Pro výpočet kritického tečného napětí $\tau_{c}$ a koeficientu erodovatelnosti $k_{d}$ byl použit nástroj „Jet Erosion Test Spreadsheet Tool“ [19]. Tento tabulkový nástroj (MS Excel) vyvinuli Hanson a Cook [11]. Do nástroje použili rovnice, které stanoví kritické tečné napětí $\tau_{c}$ na základě maximálního prohloubení erozního kráteru. 
Koeficient erodovatelnosti $k_{d}$ je poté stanoven pomocí předem vypočítaného kritického tečného napětí, bezrozměrné funkce času T* a bezrozměrné funkce hloubky J* [11]. Tento nástroj byl následně ještě několikrát vylepšen [10, 19], byly do něj přidány alternativní metody stanovení erozních parametrů. Jedním z príistupů řešení je tzv. Blaisdellova metoda (BM), v níž se erozní parametry počítají na základě dat o hloubce a času, které se prokládají hyperbolickou funkcí [21]. Zbylé dvě metody "Scour depth" a Iterační jsou variacemi Blaisdellovy metody. $U$ Iterační metody jsou zpočátku erozní parametry $\tau_{c}$ a $k_{d}$ odhadnuty pomocí Blaisdellovy metody, parametry erodibility jsou rešeny iteračně. Cílovou funkcí pro tuto Iterační metodu je minimalizace chyby mezi měřeným a predikovaným časem. Je zde ovšem horní hranice $\tau_{c^{\prime}}$ aby se zabránilo překročení rovnovážné hloubky. V metodě "Scour depth" jsou erozní parametry také řešeny iteračně. Cílovou funkcí pro tuto metodu je minimalizace chyby mezi naměřenými hloubkami a predikovanými údaji o hloubce. Výsledky této metody ukazují lepší přiblížení naměřeným hodnotám hloubek, ale hodnoty koeficientu erodovatelnosti mohou být $v$ některých prípadech nadhodnocovány [9].

Pro prípad nesoudržných půd byla použita metoda "Scour depth“, jelikož pomocí ní se průběhy naměřených hloubek erozních kráterů nejvíce přibližují predikovanému průběhu hloubky. Jednotlivé metody vyhodnocení Mini-JET experimentů jsou popsány $v$ pracích $[9,10,21]$.

Před výpočty byly do výpočetního nástroje zadány parametry zařízení: průměr trysky 3,2 mm a hodnota kalibračního koeficientu 0,696. Následně byly vypočteny hodnoty erozních parametrů. Ze 75 simulací bylo při určování erodovatelnosti 23 simulací vyřazeno. Důvodem bylo nerovnoměrné prohlubování kráteru, způsobené nehomogenitou půdního prostředí, kvůli kterému průběh hloubky kráteru neodpovídal výpočetní metodě „Scour depth“.

\section{VÝSLEDKY}

Z použitých simulací byly vypočteny erozní parametry, jež jsou uvedeny v tabulkách níže (tab. 2, tab. 3).

\section{Tab. 2. Výsledné hodnoty kritického tečného napětí}

Tab. 2. Measured values of critical shear stress

\begin{tabular}{lcccc}
\hline \multirow{2}{*}{ Povrch } & \multicolumn{4}{c}{ Kritické tečné napětí [Pa] } \\
\cline { 2 - 5 } & Min. & Max. & Průměr & Sm. odch. \\
\hline Válcovaný úhor (8. 7. 2020) & 1,3 & 1,8 & $\mathbf{1 , 5}$ & 0,2 \\
\hline Válcovaný úhor (10. 9. 2020) & 1,0 & 1,5 & $\mathbf{1 , 2}$ & 0,2 \\
\hline Setové lože (21. 10. 2020) & 3,8 & 7,9 & $\mathbf{5 , 5}$ & 1,6 \\
\hline Setové lože (24. 10. 2020) & 3,8 & 9,5 & $\mathbf{5 , 5}$ & 1,5 \\
\hline Setové lože (25. 10. 2020) & 2,6 & 10,2 & $\mathbf{6 , 5}$ & 1,7 \\
\hline
\end{tabular}

Vypočtené hodnoty průměrného kritického tečného napětí pro povrchy válcovaného úhoru se pohybují od 1,2 Pa do 1,5 Pa (tab. 2). Variabilita těchto hodnot je nízká (směrodatná odchylka 0,2 Pa). Tato variabilita je pravděpodobně způsobena drobnými rozdíly mezi půdními povrchy, jako jsou rozdílná objemová hmotnost, počáteční vlhkost či různá stabilita půdních agregátů. Jelikož u povrchu válcovaného úhoru nebyly měřeny hodnoty stability půdních agregátů a obsahu organického uhlíku, nelze jednoznačně určit důvod variability. $\checkmark$ neposlední řadě může být mírná variabilita způsobena procesními chybami, které vznikly během simulací a vyhodnocení.

Vypočtené hodnoty průměrného kritického tečného napětí pro povrchy setového lože dosahujívyšších hodnot (5,5-6,5 Pa) nežu válcovaného úhoru. Toje způsobeno především vyšší objemovou hmotností. U setového lože byla zaznamenána vyšší variabilita výsledných hodnot (směrodatná odchylka 1,5-1,7 Pa). Tato variabilita je pravděpodobně způsobena stejnými vlivy jako $v$ předešlém prípadě, u setového lože jsou však prostorově ještě výraznější.

Tab. 3. Výsledné hodnoty koeficientu erodovatelnosti Tab. 3. Measured values of the erodibility coefficient

\begin{tabular}{lrrrr}
\hline \multirow{2}{*}{ Povrch } & \multicolumn{3}{c}{$\begin{array}{l}\text { Koeficient erodovatelnosti } \\
{\left[\mathbf{c m}^{\mathbf{3}} \cdot \mathbf{N}^{-1} \cdot \mathbf{s}^{-1}\right]}\end{array}$} & \\
\cline { 2 - 5 } & Min. & Max. & Průměr & Sm. odch. \\
\hline Válcovaný úhor (8. 7. 2020) & 182,5 & 1594,0 & $\mathbf{7 7 0 , 0}$ & 600,0 \\
\hline Válcovaný úhor (10. 9. 2020) & 448,5 & 1415,1 & $\mathbf{8 8 1 , 4}$ & 280,8 \\
\hline Setové lože (21. 10. 2020) & 19,2 & 424,2 & $\mathbf{1 2 1 , 2}$ & 132,6 \\
\hline Setové lože (24. 10. 2020) & 12,4 & 315,2 & $\mathbf{1 1 1 , 3}$ & 88,8 \\
\hline Setové lože (25. 10. 2020) & 8,2 & 621,0 & $\mathbf{1 4 8 , 8}$ & 183,1 \\
\hline
\end{tabular}

Průměrné hodnoty koeficientu erodovatelnosti pro válcovaný úhor dosahují $770,0-881,4 \mathrm{~cm}^{3} \cdot \mathrm{N}^{-1} \cdot \mathrm{s}^{-1}$ a vykazují vysokou variabilitu (tab. 3). Důvodem variability jsou především značná nesoudržnost půdy (předem nakypřená a uválcovaná) a také vysoká citlivost koeficientu erodovatelnosti na změny ve velmi nízkých hodnotách kritického tečného napětí.

Prưměrné hodnoty koeficientu erodovatelnosti setového lože jsou výrazně nižší $\left(111,3-148,8 \mathrm{~cm}^{3} \cdot \mathrm{N}^{-1} \cdot \mathrm{s}^{-1}\right)$, ale také vykazují vysokou variabilitu. Jelikož je tato půda soudržnější, hodnoty koeficientu erodovatelnosti jsou nižší. Příčiny vysoké variability jsou pravděpodobně stejné jako u válcovaného úhoru.

\section{DISKUZE}

Pro otestování modifikovaného zařizení Mini-JET byly využity dva typy půdního povrchu. Byl to povrch válcovaného úhoru o objemové hmotnosti 1,35 g.cm-3 a počáteční objemové vlhkosti 19,5\%, a povrch setového lože o objemové hmotnosti 1,83 g.cm-3, počáteční vlhkosti 30,6 \%, stabilitě půdních agregátů $58,2 \%$ a obsahu organického uhlíku 1,53\%. Půda byla klasifikována jako prachovitá hlína (jíl - 9,0\%, prach - 56,3\%, písek - 34,7\%).

Po experimentech byl proveden výpočet erozních parametrů. U válcovaného úhoru byla průměrná hodnota kritického tečného napětí 1,4 Pa se směrodatnou odchylkou 0,2 Pa a průměrná hodnota koeficientu erodovatelnosti byla $825,7 \mathrm{~cm}^{3} \cdot \mathrm{N}^{-1} \cdot \mathrm{S}^{-1}$ se směrodatnou odchylkou $440,4 \mathrm{~cm}^{3} \cdot \mathrm{N}^{-1} \cdot \mathrm{s}^{-1}$. Jelikož se $v$ této studii testovalo zař́zení Mini-JET poprvé na značně nesoudržné půdě, nelze výsledky s jinými obdobnými měřeními prímo porovnat.

Půdní povrch setového lože byl soudržnější, průměrná hodnota kritického tečného napětí dosahovala 5,80 Pa, což je srovnatelné s měřením Mahaldera a kol. [9], kteří testovali půdu o objemové hmotnosti 1,80 g. $\mathrm{cm}^{-3}$ a vlhkosti okolo 30 \%. Při použití metody „Scour depth“ Mahalder a kol. [9] uvádějí výsledné průměrné kritické tečné napětí 6,9 Pa se směrodatnou odchylkou 3,8 Pa.

Průměrná hodnota koeficientu erodovatelnosti byla $127,1 \mathrm{~cm}^{3} \cdot \mathrm{N}^{-1} \cdot \mathrm{s}^{-1}$ se směrodatnou odchylkou $134,8 \mathrm{~cm}^{3} \cdot \mathrm{N}^{-1} \cdot \mathrm{s}^{-1}$. Mahalder a kol. [9] uvádí výrazně nižší hodnotu, konkrétně $12,3 \mathrm{~cm}^{3} \cdot \mathrm{N}^{-1} \cdot \mathrm{s}^{-1}$ se směrodatnou odchylkou $13,0 \mathrm{~cm}^{3} \cdot \mathrm{N}^{-1} \cdot \mathrm{s}^{-1}$. Nesourodost výsledků je způsobena pravděpodobně tím, že dosavadní studie [9-11] se věnovaly testováním zařizení na soudržných půdách (zejména půdy na březích vodních toků), oproti tomu tato studie testuje zařizení na nesoudržných půdách. Nicméně i zde dosahovala směrodatná odchylka měření stejných řádů 
jako naměřené hodnoty koeficientu erodovatelnosti. Pomocí metody „Scour depth" testovali soudržnost půdního povrchu také Daly a kol. [10], kteří u soudržných půd změřili kritické tečné napětí v rozmezí 1,2-16,4 Pa a koeficient erodovatelnosti $2,0-210,8 \mathrm{~cm}^{3} \cdot \mathrm{N}^{-1} \cdot \mathrm{s}^{-1}$.

Velká variabilita erozních veličin zjištěná při měřeních se zařízeními typu JET nebo Mini-JET je tak charakteristická pro všechny typy půdních povrchů. Přesto jsou na různých půdách s odlišnou soudržností prokazatelně naměřeny hodnoty erodovatelnosti, jež jsou využitelné pro implementaci v erozních modelech. Na základě provedených testů Ize proto konstatovat, že metodu Ize uplatnit i na zemědělských půdách. Pro získání relevantních hodnot erodovatelnost je však třeba provést vždy dostatečný počet replikací, aby i přes variabilitu naměřených hodnot byly průměrné hodnoty erodovatelnosti statisticky jasně prokazatelné.

Zde jsou uvedeny nejistoty a chyby, které mohly vzniknout při samotném terénním měření nebo při pozdějších výpočtech:

- Nedokonalé odvzdušnění systému - při nedostatečném odvzdušnění dochází k nesprávnému měření manometru a hodnoty nemusejí odpovídat skutečnosti. To se negativně promítne do vypočtených erozních koeficientů. Tato chyba byla kontrolou systému minimalizována.

- Nehomogenní půdní prostředí - metodika výpočtu erozních parametrů předpokládá homogenní půdní prostředí v místě simulace. Pokud půdní prostředí není homogenní, např. výskytem preferenčních makropórů (hlodavci aj.), dochází k ovlivnění výsledné hodnoty erozních parametrů.

- Ovládání hloubkového měřidla - pokud při měření dojde k př́liš rychlému spuštění měřidla do kráteru, měřidlo se do půdy zaboří. Čtení je potom nadhodnocené a dno kráteru je pro následující časový úsek měření znehodnoceno. Vždy je potřeba hloubkové měřidlo spouštět do erozního kráteru pomalu a opatrně.

— Výskyt nežádoucího předmětu v půdě - jestliže se prímo v erozním kráteru vyskytne nežádoucí předmět, jako jsou např́klad kameny či kořeny, prohlubování kráteru se zastaví.

- Chybně určený kalibrační koeficient zařízení - nesprávně stanovený kalibrační koeficient pro konkrétní zařizení vede k chybnému výpočtu erozních charakteristik.

\section{ZÁVĚR}

Cílem této práce bylo stanovit erodovatelnost nesoudržných zemědělských půd pomocí měření kritického tečného napětí. Pro určení kritického napětí byla využita inovativní technika založená na tzv. „Jet Erosion Testu“, erozní experimenty byly prováděny s využitím modifikovaného zařízení Mini-JET. U testovaného prístroje byla provedena kalibrace pro stanovení kalibračního koeficientu, který byl následně použit pro výpočet erozních parametrů. Následně bylo provedeno testování přístroje, jež probíhalo na experimentálních plochách u obce Řisuty (kambizem modální, prachovitá hlína). Testování probíhalo na dvou typech půdních povrchů (válcovaný úhor, setové lože). Pomocí metody „Scour depth" byly vypočteny kritické tečné napětí a koeficient erodovatelnosti.

Celkem bylo provedeno 75 simulací, z toho 23 simulací nebylo možno z důvodu nerovnoměrného průběhu využít pro určení erozních parametrů. Úspěšnost výpočtu erozních parametrů tak činila 69,3\%. Pro konsolidovaný půdní povrch po predchozích srážkách v úhrnu $35 \mathrm{~mm}$ bylo oproti čerstvě nakypřenému a válcovanému úhoru naměřeno čtyřikrát vyšší kritické tečné napětí (5,8 Pa oproti 1,4 Pa). To odpovídá přibližně 6,5krát nižšímu koeficientu erodovatelnosti. Z výsledku je zřejmé, že konsolidace povrchu vlivem předchozích srážek, vysychání a vznikající pưdní krusta se výrazně podílejí na snižení erodovatelnosti, tedy zvýšení odolnosti půdy proti dalšímu rozrušování erozně účinnou srážkou. Čerstvě připravený úhor a relativně suchý povrch inned po zasetí (počáteční objemová vlhkost $19 \%$ ) je při identických podmínkách více náchylný k erozi než konsolidovaný povrch s měsíčním odstupem po kultivaci a s vyšší objemovou vlhkostí. Vztah ostatních parametrů k erodovatelnosti se prozatím nepodařilo experimentem prokázat.

Výrazná variabilita naměřených výsledků (směrodatná odchylka v rádu naměřených hodnot erodovatelnosti) je u podobných experimentů běžná, upozorňuje však na významnou nejistotu jednoho konkrétního měření, proto je třeba vždy provést dostatečný počet experimentư pro určení průkazných výsledků. I z toho důvodu byly rovněž popsány možné nejistoty a chyby, jichž se může uživatel této metody dopustit. $V$ dalších experimentech bude cílem rovněž minimalizace možných metodických chyb. Z vypočtených výsledků erozních parametrů, které byly porovnány se zahraničními studiemi provedenými na soudržnějších půdách, vyplynulo, že zařizení použité v této studii lze použít pro měření kritického tečného napětí i na nesoudržných půdách, jakými jsou charakterizovány např́klad zemědělské pozemky po předsetové prípravě a $v$ průběhu sezony.

\section{Poděkování}

Tato práce byla podpořena výzkumnými projekty LTAUSA19019, QK1920224, QK1810341 a SGS20/156/OHK1/3T/11.

\section{Literatura}

[1] POESEN, J. Soil erosion in the Anthropocene: Research needs. Earth Surface Processes and Landforms [on-line]. 2018, 43(1), s. 64-84. ISSN 10969837. Dostupné z: doi:10.1002/esp.4250

[2] BÁČOVÁ, M., KRÁSA J. Application of historical and recent aerial imagery in monitoring water erosion occurrences in Czech highlands. Soil and Water Research [on-line]. 2016, 11(No. 4), s. 267-276. ISSN 18015395. Dostupné z: doi:10.17221/178/2015-SWR

[3] WISCHMEIER, W. H., SMITH, D. D. Predicting rainfall erosion losses. Agriculture handbookno. 537. 1978, (537). ISSN 0002-8606.

[4] VAN ROMPAEY, A., VERSTRAETEN, G., VAN OOST, K., GOVERS, G., POESEN, J. Modelling mean annual sediment yield using a distributed approach. Earth Surface Processes and Landforms [on-line]. 2001, 26(11). ISSN 01979337. Dostupné z: doi:10.1002/esp.275

[5] MORGAN, R. P. C., NEARING, M. A. Handbook of Erosion Modelling [on-line]. 2011. Dostupné z: doi:10.1002/9781444328455

[6] SCHMIDT, J. A mathematical model to simulate rainfall erosion. Catena Supplement. 1991, 19.

[7] RENARD, K. G, FOSTER, G. R., WEESIES, G. A., MCCOOL, D. K., YODER, D. C. Predicting soil erosion by water: a guide to conservation planning with the Revised Universal Soil Loss Equation (RUSLE) [on-line]. 1997. ISBN 0160489385. Dostupné z: doi:DC0-16-048938-5 65-100

[8] LÉONARD, J., RICHARD, G. Estimation of runoff critical shear stress for soil erosion from soil shear strength. Catena [on-line]. 2004, 57(3), s. 233-249. ISSN 03418162. Dostupné z: doi:10.1016/j. catena.2003.11.007

[9] MAHALDER, B., SCHWARTZ, J. S., PALOMINO, A. M., ZIRKLE, J. Estimating erodibility parameters for streambanks with cohesive soils using the mini jet test device: A comparison of field and computational methods. Water (Switzerland) [on-line]. 2018, 10(3), s. 1-20. ISSN 20734441. Dostupné z: doi:10.3390/w10030304

[10] DALY, E. R., FOX, G. A., AL-MADHHACHI, A. T., MILLER, R. B. A scour depth approach for deriving erodibility parameters from jet erosion tests. Transactions of the ASABE [on-line]. 2013, 56(6), s. 1343-1351. ISSN 21510032. Dostupné z: doi:10.13031/trans.56.10350

[11] HANSON, G. J., COOK, K. R. Apparatus, test procedures, and analytical methods to measure soil erodibility in situ. Applied Engineering in Agriculture. 2004, 20(4), s. 455-462. ISSN 08838542.

[12] VRÁNA, M. Testovánínové konstrukce Minijetu pro odhad kritického tečného napětí v erozním výzkumu. B. m., 2021. České vysoké učení technické v Praze

[13] HANSON, G. J., ROBINSON, K. M., TEMPLE, D. M. Pressure and stress distributions due to a submerged impinging jet. Hydraulic Engineering - Proceedings of the 1990 National Conference. 1990, s. 525-530

[14] HANSON, G. J., COOK, K. R. Development of excess shear stress parameters for circular jet testing. Paper-American Society of Agricultural Engineers. 1997, 2. ISSN 01450166.

[15] KHANAL, A., FOX, G. A., AL-MADHHACHI, A. T. Variability of Erodibility Parameters from Laboratory Mini Jet Erosion Tests. Journal of Hydrologic Engineering [on-line]. 2016, 21(10), 04016030. ISSN 1084-0699. Dostupné z: doi:10.1061/(asce)he.1943-5584.0001404 


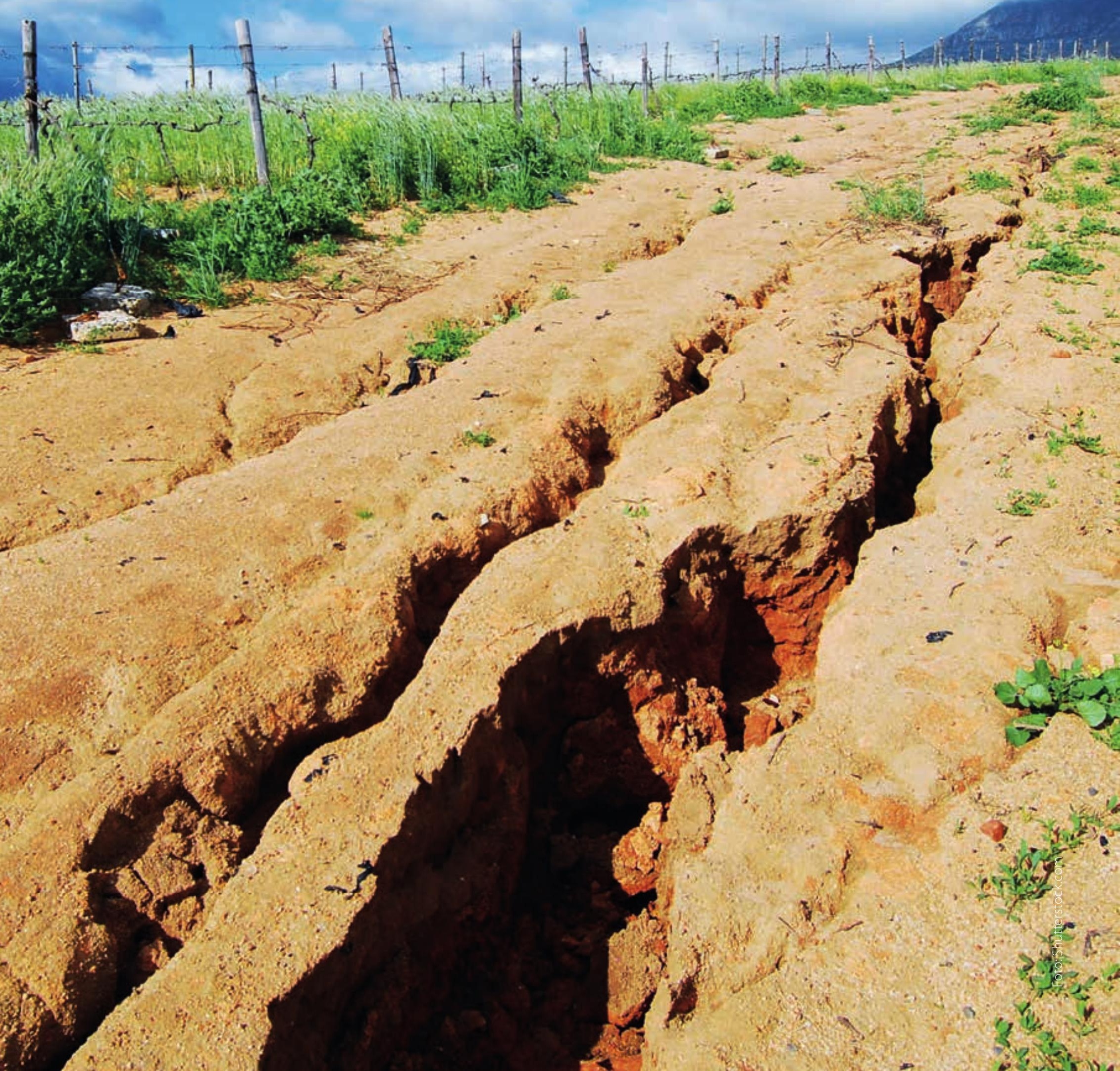


[16] AL-MADHHACHI, A. T., HANSON, G. J, FOX, G. A., TYAGI, A. K., BULUT, R. Deriving Parameters of a Fundamental Detachment Model for Cohesive Soils from Flume and Jet Erosion Tests. Transactions of the ASABE [on-line]. 2013, 56(2), s. 489-504. ISSN 2151-0032. Dostupné z: doi:10.13031/2013.42669

[17] SIMON, A., THOMAS, R. E., KLIMERTZ, L. Comparison and Experiences With Field Techniques TO Measure Critical. 2nd Joint Federal Interagency Conference, Las Vegas. 2010, 826, 13

[18] AL-MADHHACHI, A. T., HANSON, G. J., FOX, G. A., TYAGI, A. K., BULUT, R. Measuring soil erodibility using a laboratory "Mini" JET [on-line]. 2013, 56(3), s. 901-910. Dostupné z: doi:10.13031/trans.56.9742

[19] MAHALDER, B. Jet Erosion Test Spreadsheet Tool. 2014

[20] ROUDNICKÁ, A, DOSTÁL, T., KRÁSA, J., MISTR, M., NOVOTNÝ, I., ZUMR, D., KAVKA, P., NEUMANN, M, STAŠEK, J. Způsob stanovení ochranného vlivu vegetace před erozí půdy pomocí mobilního deštového simulátoru. Vodníhospodářství. 2018, 12, s. 18-23

[21] BLAISDELL, F. W., ANDERSON, C. L., HEBAUS, G. G. Ultimate dimensions of local scour. Journa of the Hydraulics Division, ASCE [on-line]. 1981, 107(HY3, Proc. Paper, 16144). ISSN 2690-2524. Dostupné z: doi:10.1061/JYCEAJ.0005630

\section{Autoři}

Ing. Michal Vrána ${ }^{1}$

凶michal.vrana@fsv.cvut.cz

ORCID: 0000-0002-9849-0217

Ing. David Zumr, Ph.D. ${ }^{1}$

凶david.zumr@fsv.cvut.cz

ORCID: 0000-0002-0330-7716

doc. Ing. Josef Krása, Ph.D.

凶josef.krasa@fsv.cvut.cz

ORCID: 0000-0003-4067-5806

doc. Dr. Ing. Tomáš Dostál ${ }^{1}$

凶dostal@fsv.cvut.cz

ORCID: 0000-0003-3984-3462

prof. John S. Schwartz, Ph.D. ${ }^{2}$

凶jschwart@utk.edu

ORCID: 0000-0001-6880-3633

'Katedra hydromeliorací a krajinného inženýrství, Fakulta stavební, ČVUT v Praze

${ }^{2}$ Department of Civil and Environmental Engineering,

The University of Tennessee, Knoxville

Příspěvek prošel lektorským řízením.

\section{MINI-JET DEVICE AS A TOOL FOR DETER- MINATION OF SOIL ERODIBILITY CHARACTERISTICS}

\section{VRÁNA, M.'; ZUMR, D.'; KRÁSA, J.'; DOSTÁL, T.'; SCHWARTZ, J. S. ${ }^{2}$}

${ }^{1}$ Czech Technical University in Prague, Faculty of Civil Engineering ${ }^{2}$ Department of Civil and Environmental Engineering, The University of Tennessee, Knoxville

Keywords: Mini-JET — critical shear stress - erodibility coefficient incohesive soil

The article describes a method for determining the erodibility of incohesive agricultural soils by means of the critical shear stress measuring. The "Jet Erosion Test" (JET) was used to determine the critical shear stress. The measurement was performed using a modified Mini-JET device. The device is very suitable for field measurements, because it is small, light, requires a relatively small amount of water, and can be operated by single person. The principle of measuring the critical shear stress of the soil is based on monitoring the rate of erosion crater formation by the action of a water jet of known kinetic energy. Based on the erosion crater development, the erosion parameters of the soil, such as the critical shear stress and the erodibility coefficient, can be calculated.

All Mini-JET experiments were performed on experimental plots near Řisuty (central Czechia). Two different types of soil surface were utilized for the experiments. Bulk density, soil texture, soil water content, aggregate stability, and total organic carbon were determined. A total of 75 simulations were performed.

A large variability of the soil parameters was found, which is characteristic for agricultural topsoils. Nevertheless, the determined values of the erodibility coefficient are comparable with the previously published values and can thus be used for implementation in the physically based soil erosion models. Based on the tests performed, it can be stated that the Mini-JET method is feasible for agricultural soils. However, in order to obtain representative erodibility values, a sufficient number of replications must be performed.

DOI: $10.46555 /$ VTEI.2021.07.001 